5. Rost K, Pyne JM, Dickinson LM, Elliott CE, deGruy F. The cost effectiveness of enhancing primary care depression management on an ongoing basis. Ann Fam Med. 2005;3:7-14.

6. deGruy F. Depression care: progress and prospects. Ann Fam Med. 2005;3:3-6.

7. Spurling MC, Vinson DC. Alcohol-related injuries: evidence for the prevention paradox. Ann Fam Med. 2004;2:47-52.

8. Rost K, Pyne JM, Dickinson LM, et al. Physician conceptions of responsibility to individual patients and distributive justice in healthcare. Ann Fam Med. 2005;3:53-59.

9. Koopman RJ, Mainous AG, Diaz VA, Geesey ME. Changes in age at diagnosis of type 2 diabetes in the United States, 1988-2000. Ann Fam Med. 2005;3:60-63.

10. Meadows LM, Mrkonjic L, Lagendyk L. Women's perceptions of future risk after low energy fractures at midlife. Ann Fam Med. 2005;3:64-69.
11. Chené R, García L, Goldstrom M, et al. Mental health research in primary care: mandates from a community advisory board. Ann Fam Med. 2005;3:70-72.

12. Chené R, García L, Goldstrom M, et al. Mental health research in primary care: mandates from a community advisory board. Appendix. Available at: http://www.annfammed.org/cgi/content/full/3/1/ 70/DC1.

13. Glasgow RE, Ory MG, Klesges LM, Cifuentes M, Fernald DH, Green LA. Practical and relevant self-report measures of health behavior for primary care settings. Ann Fam Med. 2005;3:73-81.

14. Glasgow RE, Ory MG, Klesges LM, Cifuentes M, Fernald DH, Green LA. Practical and relevant self-report measures of health behavior for primary care settings. Appendix. Available at: http://www. annfammed.org/cgi/content/full/3/1/73/DC1.

15. Brody $\mathrm{H}$. The company we keep: why physicians should refuse to see pharmaceutical representatives. Ann Fam Med. 2005;3:82-85

\title{
EDITORIAL
}

\section{Depression Research in Primary Care: Pushing the Field Forward}

Frank de Gruy III, MD

University of Colorado, Aurora, Colo

Ann Fam Med 2005;3:3-6. DOI: 10.1370/afm.274

$\mathrm{T}$ his issue of the Annals contains a suite of studies dealing with mental health care, particularly the care we render to depressed patients in the primary care setting. I hope every reader reads these articles, because they are solid, scientifically sophisticated studies that advance the field - that lead us toward better care of our depressed patients. And they are more than that. In just a moment we will look specifically at where some of these discoveries are leading us, but first a few general thoughts.

For some of us, the early 1990s were when the lessons from the foray of this nation into managed care began to really sink in. In primary care one of those

Conflict of interest: none reported.

\section{CORRESPONDING AUTHOR}

Frank de Gruy III, MD

Department of Family Medicine

UCHSC at Fitzsimons

PO Box 6508 - Mail Stop F496

Aurora, CO 80045-0508

frank.degruy@uchsc.edu forays was the creation of hard-partition mental health carveouts, and one lesson was that this so-called solution to the problem of expensive mental health care itself created even larger problems. We faced the difficulty of practicing integrated, comprehensive primary care within a disintegrative structure. Not only were carveouts difficult to work with, but no one asked us whether we wanted them-this structure was delivered to us as a fait accompli, the prescribed, received world in which we practiced. So we published polemics about the necessity of rendering mental health care in the primary care setting. ${ }^{1}$ We took on (and sometimes became) health plan managers, looking for ways to break down, work around, or work within this onerous barrier. We sought solutions among our cousins in cognate fields that might map to our problems (we have borrowed freely, for example, from the literature on chronic disease management ${ }^{2}$ and imported the structures and resources necessary for our success).

Look at this field today! We're not talking about whether we should manage depression in our practices, but bow. That is progress. It didn't come by killing carveouts (as if that were possible). It came by work- 
ing with them. In fact, one of the most interesting and innovative programs of research in primary care today, Depression in Primary Care: Integrating Clinical and System Strategies, ${ }^{3}$ sponsored by the Robert Wood Johnson Foundation, is explicitly supporting a number of studies that make partnerships between health plans that manage primary care practices and those that manage mental health carveouts. Some of these studies are beginning to show encouraging results. So there is value in staying focused on the grail of integrated comprehensive care, even in the teeth of forces colluding against it, and plowing ahead, trying to find ways to overcome whatever barriers arise, however hopeless it appears. We should take sustenance from our progress-it should inspire us to continue struggling for the right kind of primary care.

Another general lesson can be found in the extraordinary article by Chené et al. ${ }^{4}$ Twenty years ago mental health services researchers, as well as general primary care researchers, were coming to grips with the legitimacy of qualitative and mixed methods studies. At first it was difficult to get these studies funded, and therefore difficult to do the high-quality, high-impact work that would vindicate this new methodology. Today we have hundreds of such studies in our literature, including the one from Baik et al, ${ }_{1}^{5}$ published in this issue, that yield valuable insights into our patients, our practices, and ourselves. This methodology is now accepted by study sections, editors, and readers alike. In an analogous fashion, we have seen in recent years suggestions that a new research methodology-community-based participatory research-might be helpful against some of the problems we are studying. I have personally witnessed the skepticism this methodology has engendered among grant reviewers, who fret about the loss of scientific objectivity and the drift from ante boc hypothesis testing inherent in the accommodation of subjects' agendas.

In this issue we have a breathtaking account of what we can gain by such an accommodation, and what we risk losing by not. If you read nothing else in this issue, read the Chené et al article. If you read nothing else in this issue, read the appendix to this article. Within the first 3 paragraphs Wendy Grey Eyes Thunderchief, with her tender, funny, and penetrating story, demolishes our assumptions about the veracity of our vaunted objective data. That's just the beginning of an utterly compelling account by members of a community advisory board. Just as nonhomogeneous study samples and usual care comparison groups have become standard devices for effectiveness trials, just as nested designs and hierarchical modeling have become standard devices for PBRN-based studies, so, I believe, will participatory research soon take its place as one of our fundamental methods-one of our core strategies for learning the truth about primary health care. This article makes the most compelling case we have so far for this conviction.

Perhaps the best way to manage a discussion about what these articles specifically offer us is to deploy them along the "6 $\mathrm{P}^{\prime}$ conceptual framework described by Pincus et al. ${ }^{6}$ This framework simply describes 6 different levels at which barriers occur, and at which interventions can be aimed, when managing depression in primary care. Pincus et al argue that to achieve maximum benefit, we need to consider barriers and interventions at each of the following 6 levels: the patient, the provider, the practice, the health plan, the purchaser, and the population. Even though we are nowhere near having produced the kind of primary care practice in which all depressed patients are identified and treated to remission, it turns out that by now there is a robust literature on the management of depression in primary care, with specific attention to factors at each of these levels. Our knowledge, however, becomes attenuated as we ascend this hierarchy toward the health plan and purchaser end of the continuum. There is an emerging consensus that improvements in depression can be created with attention to issues at the first 3 levels, but that sustainability of improvements requires attention at least to the last 2.

One could say that the 6 articles presented here represent efforts at each of these 6 levels, and thus collectively push the field forward on every front. This is not to say that every aspect of depression care needing research is addressed, of course, but that every domain containing research activity has a representative here.

At the patient level, Aikens et $\mathrm{al}^{7}$ address the problem of nonadherence to the maintenance phase of pharmacotherapy, and develop a 4-cell medication belief profile that discriminates between patients more and less likely to continue maintenance phase treatment. This profiling scheme also suggests differential adherence promotion strategies, which could form an attractive basis for future study. At the provider level, Baik et al, ${ }^{5}$ having observed that provider education does not itself insure recognition of depression, conducted a small, elegant qualitative study identifying 3 processes that clinicians apply differentially, according to the context in which they are evaluating their patient, that seem to determine whether the diagnosis of depression is entered or even entertained. This study incidentally reinforces the value of continuity of care, inasmuch as "recognizing the person" can lead to an accurate diagnosis of depression even in a brief encounter.

At the practice level and the plan level, Dickinson et $\mathrm{al}_{,}^{8}$ examining data from a clinical trial in which a chronic disease management protocol was introduced 
into practices, discovered that the protocol benefited patients who reported psychological symptoms (at less cost than usual), but not patients who reported physical symptoms (even though the intervention was relatively expensive in this group). Three obvious implications follow from these results: we need to find different interventions for somatically oriented patients, we have a cost-offset effect for patients complaining of psychological symptoms, and we need to remember to always look for differential effects among subsets of our patients, regardless of whether we're talking about depression.

At the plan level and the purchaser level, Rost et a $1^{9}$ show that depression treatment in primary care can be rendered so that employers - purchasers-benefit in terms of work productivity and improved absenteeism beyond the cost of the treatment intervention. This casts into relief the necessity of describing benefits (ie, outcomes) of our interventions in terms that are meaningful to those who can act on them.

At the population level, Van Voorhees et $\mathrm{al}^{10}$ have analyzed a large-community adolescent data set and discovered the reasons why one fourth of these patients would not accept a diagnosis of depression, even though meeting the criteria. Finally, Chené et $\mathrm{al}^{4}$ bring the perspective of a community advisory board to the problems of researching mental health problems, a perspective that we ignore at our peril.

What does this add up to? Unhappily, we are not done. We can see the need to consider the patient, physician, practice, plan, and purchaser, but these factors have not converged into simple practice recommendations. There is still a lot of research work to do at each of these levels, not to mention the work of integrating them into coherent guidelines. We are years away from feeling that this problem of managing depressed patients in primary is anywhere near solved.

Two articles appearing in this issue, by Dickinson et al and by Rost et al, use a chronic disease management model as the basis for improved depression care. This model, which calls for the use of a care manager, a registry, condition-specific patient and clinician education and activation modules, and management guidelines, is beginning to enjoy extensive deployment in primary care settings against a host of chronic conditions. It works. We probably have more experience using the chronic disease management model for depression than for any chronic illness, and a number of interesting chronic disease management questions are beginning to be addressed by depression researchers. For example, should care managers be nurses, nurse clinicians, social workers, patient educators, or something else? Does it matter? Should they be devoted to a single condition, or can they be as effec- tive against a number of chronic conditions simultaneously? How does a practice pay for them? Do they have to be physically located in the office? Can they be as effective for prevention as for chronic disease management? These and many other questions are beginning to be answered by depression researchers, and each of us will benefit from the answers, even if we do not actually manage depression.

Today we are facing a development that is eerily reminiscent of the mental health carveout story of 2 decades ago: there are now companies offering chronic disease management carveouts to health plans. As before, such a carveout could cause two bad outcomes. First, if these companies succeed, chronic disease management could disappear from primary care. Second, even if these programs stay within the primary care setting, depression could fall off the list as a disease addressed by these programs. If chronic disease management is a good model for all primary care, including prevention and acute problems and not just chronic diseases, a chronic disease carveout could eviscerate primary care and leave us with as fragmented and ineffective a health care system as we feared 20 years ago. We have a lot to learn about how to do primary care from the lessons we are learning about depression care. We should pay particular attention to the developments in the field concerning the use of care managers for multiple conditions. We should pay attention to the plan-level resources that can be made available to help us with chronic disease management. We should pay attention to the kinds of outcomes that purchasers respond to and incorporate them into our standard outcomes. Above all, we should conscientiously assess the overall value to our patients of managing depression and other mental conditions in the primary care setting, and measure what's lost when these are managed outside our setting.

To read or post commentaries in response to this article, see it online at http://www.annfammed.org/cgi/content/full/3/1/3.

Key words: Depression, primary health care; qualitative research; managed care programs; health promotion

Submitted December 8; accepted December 13, 2004.

\section{References}

1. deGruy FV. Mental health care in the primary care setting. In: MS Donaldson, KD Yordy, KN Lohr and NA Vanselow, eds. Primary Care: America's Health in a New Era. Washington, DC: Institute of Medicine, National Academy Press; 1996:285-311

2. Wagner EH, Austin BT, Von Korff M. Organizing care for patients with chronic illness. Milbank Q. 1996;74:511-544.

3. Robert Wood Johnson Foundation. Depression in primary care: linking clinical and system strategies. Available at: http://www.depression inprimarycare.org. 
4. Chené R, García L, Goldstrom M, et al. Mental health research in primary care: mandates from a community advisory board. Ann Fam Med. 2005;3:70-72.

5. Baik S, Bowers BJ, Oakley LD, Susman JL. The recognition of depression: the primary care provider's perspective. Ann Fam Med. 2005:3:31-37.

6. Pincus HA, Hough L, Knox Houtsinger J, Rollman BL, Frank RG: Emerging models of depression care: Multilevel ("6 P") strategies. Int J Meth Psychiatr Res. 2003;12:54-63.

7. Aikens JE, Nease DE, Nau DP, Klinkman MS, Schwenk TL. Adherence to maintenance-phase antidepressant medication as a function of beliefs about medication. Ann Fam Med. 2005;3:23-30.
8. Dickinson LM, Rost K, Nutting PA, Elliott CE, Keeley RD, Pincus $H$. Care manager for major depression in primary care: costs of outpatient care over two years comparing patients with physical versus psychological symptoms. Ann Fam Med. 2005;3:15-22.

9. Rost K, Pyne JM, Dickinson LM, Elliott CE, deGruy F. The cost effectiveness of enhancing primary care depression management on an ongoing basis. Ann Fam Med. 2005;3:7-14.

10. Van Voorhees BW, Fogel J, Houston TK, Cooper LA, Nae-Yuh W. Beliefs and attitudes associated with the intention to not accept the diagnosis of depression among young adults. Ann Fam Med. 2005;3:38-46.

\section{CHANGE-OF-ADDRESS FORM FAMNILY MEDICINE}

Please complete this form and mail to the following address or fax to Annals Circulation at 913-906-6080:

Annals of Family Medicine, Circulation Department, 11400 Tomahawk Creek Pkwy, Leawood, KS 66211-2672

Check if member of sponsoring organization: $\square$ AAFP $\square$ ABFP $\square$ STFM $\square$ ADFM $\square$ AFPRD $\square$ NAPCRG

ID number from label on your journal cover

OLD Information (Please print.)

Name

Company (if applicable)

Address (Street plus Apt or Ste)

\begin{tabular}{ll}
\hline City & State \\
\hline Country & Postal Code (9-digit ZIP for US) \\
\hline Telephone & Fax
\end{tabular}

E-Mail
NEW Information (Please print.)

\begin{tabular}{ll}
\hline Name \\
\hline Company (if applicable) \\
\hline Address (Street plus Apt or Ste) & \\
\hline City & Postal Code (9-digit ZIP for US) \\
\hline Country & \\
\hline Telephone & \\
\hline E-Mail
\end{tabular}

